\title{
Article
}

\section{Discovery of Cell Aggregate-Inducing Peptides}

\author{
Yudai Futaki ${ }^{1}$, Ikumi Amimoto ${ }^{1}$, Megumi Tanaka ${ }^{1}$, Tomoki Ito ${ }^{1}$ and Yoshiaki Hirano ${ }^{1,2, *(D)}$ \\ 1 Faculty of Chemistry, Materials and Bioengineering, Kansai University, Suita, Osaka 564-8680, Japan; \\ y_futaki@outlook.jp (Y.F.); k307867@kansai-u.ac.jp (I.A.); biomol.eng.5885@gmail.com (M.T.); \\ grgdsppeptide5656@gmail.com (T.I.) \\ 2 Organization for Research and Development of Innovative Science and Technology, Kansai University, Suita, \\ Osaka 564-8680, Japan \\ * Correspondence: yhirano@kansai-u.ac.jp; Tel.: +81-6-6368-0974
}

Citation: Futaki, Y.; Amimoto, I.; Tanaka, M.; Ito, T.; Hirano, Y. Discovery of Cell Aggregate-Inducing Peptides. Processes 2021, 9, 538. https://doi.org/10.3390/pr9030538

Academic Editors: Yuguang Mu and Kenji Usui

Received: 26 December 2020

Accepted: 16 March 2021

Published: 18 March 2021

Publisher's Note: MDPI stays neutral with regard to jurisdictional claims in published maps and institutional affiliations.

Copyright: (c) 2021 by the authors. Licensee MDPI, Basel, Switzerland. This article is an open access article distributed under the terms and conditions of the Creative Commons Attribution (CC BY) license (https:/ / creativecommons.org/licenses/by/ $4.0 /)$.

\begin{abstract}
Most cells within the human body interact with neighboring cells and extracellular matrix (ECM) components to establish a unique 3D organization. These cell-cell and cell-ECM interactions form a complex communication network of biochemical and mechanical signals critical for normal cell physiology. The behavior of cells in a 3D environment is fundamentally different from that of cells in monolayer culture. Aggregation can affect cell-cell interactions, being more representative of the normal tissue microenvironment. Therefore, 3D cell culture technologies have been developed. The general method for cell aggregate is a physical method; it is difficult to control the size and number of cell aggregates. In any case, no chemical method has been discovered yet, so a new method to solve these problems is needed. In this paper, we describe the induction of a cell aggregate of the newly discovered (Lys-Pro) ${ }_{12}(\mathrm{KP} 24)$ peptide. Since it was revealed that KP24 had cell aggregateinducing activity, its derivatives were molecularly designed to clarify the importance of the KP24 sequence. We report that cell aggregations were induced by KP24 to form aggregates of fibroblast cells. We evaluated KP24 derivative periodic peptides such as (Lys-Pro-Pro) 8 (KPP24) and (Lys-LysPro $)_{8}(\mathrm{KKP} 24)$. The relationship between the structure of the peptide chain and the activity induced by the cell aggregations was investigated from the viewpoint of basic research and the biomedical engineering field.
\end{abstract}

Keywords: cell aggregate; 3D cell culture; Lys and Pro periodic peptide; L929 fibroblast cell

\section{Introduction}

Most cells within the human body interact with neighboring cells and extracellular matrix (ECM) components to establish a unique 3D organization. These cell-cell and cellECM interactions form a complex communication network of biochemical and mechanical signals critical for normal cell physiology. Cells in a 3D environment behave fundamentally differently from cells in monolayer culture [1-3]. Aggregation can manipulate cell-cell interactions, resulting in enhanced cell proliferation [1-4]. Conventional cell culture is performed in 2D systems, which is very different from the local environment of cells in living tissues. Therefore, 3D cell culture technologies have been developed [4,5]. Spheroids prepared from various cell types have also been used in ex vivo assays and drug screening tools in organoid and tumor research [6-10]. In addition, stem cell spheroids have demonstrated enhanced therapeutic effects when transplanted into various disease models, such as in wound healing and ischemic injury models, due to their increased growth factor secretion, immunomodulation effects, and target tissue integration [11-14]. Several culture methods including hanging drop, liquid overlay, nonadhesive plates, microwell arrays, and spinner flasks have been generally used to harvest spheroids [15]. In principle, these culture methods maximize cell-cell cohesion and induce spontaneous cellular assembly while minimizing cellular interactions with the substrate by using protein-repellant biomaterials, microstructured surfaces and physical forces such as gravitational or centrifugal forces, or 
combination thereof [16-18]. However, current methods involve labor-intensive processes, low productivity, and difficulty in spheroid size control, and thus, various alternative spheroid culture techniques using functional biomaterials have been developed.

Since this method is physical, it is difficult to control the size and number of cell aggregates. However, the larger the cell aggregate, the greater the difference in oxygen and nutrient supply and waste removal between the central part and the outer surface. In any case, no chemical method has been discovered yet, so a new method to solve these problems is needed $[4,5]$.

In the process of searching for peptides with antibacterial and anticancer activity, we discovered peptides that induce cell aggregates. Among the repeating peptides of proline (Pro) and lysine (Lys), the peptide in which proline and lysine were repeated 12 times was the most effective, and the peptide sequence was (Lys-Pro) ${ }_{12}(\mathrm{KP} 24)$. This method is a chemical cell aggregate inducting method and is a completely new concept.

In this paper, we describe the induction of cell aggregate of the newly discovered KP24 peptide. Since it was revealed that KP24 has cell aggregate-inducing activity, its derivatives were molecular designed to clarify the importance of the KP24 sequence. In order to clarify the chain length dependence of KP24, four peptide sequences of KP types with different chain lengths were molecular designed. Next, to investigate the effect of the proline residue of KP24, the proline residue was replaced with an alanine residue, KA type peptides. The positive charge of lysine residue KK type was synthesized. To also investigate the effect of the lysine residue of KP24, the lysine residue was replaced with an arginine residue. RP24 was synthesized for the control sequence. Finally, the chain length was unified to 24 residues, and peptides KKP and KPP with the different numbers of lysine and proline residues were synthesized.

The molecular designs of peptides containing proline and lysine derivatives are shown in Table 1. It was clear that when cells were cultured in the peptide-containing medium, cell aggregates were formed. Furthermore, peptide sequence and chain length dependence were evaluated by adding a peptide-containing medium to statically cultured cells and inducing cell aggregates.

Table 1. Peptide sequence of designed molecules.

\begin{tabular}{|c|c|c|}
\hline Type & Amino Acid Sequences (One Letter Amino Acid Code) & Code \\
\hline \multirow{4}{*}{ KP type } & КРКРКРКРКРКРКРКРКРКР & KP20 \\
\hline & КРКРКРКРКРКРКРКРКРКРКРКР & KP24 \\
\hline & КРКРКРКРКРКРКРКРКРКРКРКРРКРКР & KP28 \\
\hline & КРКРКРКРКРКРКРКРКРКРКРКРРКРКРРКРКР & KP32 \\
\hline \multirow{3}{*}{ KA type } & KAKAKAKAKAKAKAKA & KA16 \\
\hline & KAKAKAKАKАКАКАКАКАКА & KA20 \\
\hline & КАКАКАКАКАКАКАКАКАКАКАКА & KA24 \\
\hline \multirow{3}{*}{ KK type } & КККККККККККККККК & K16 \\
\hline & КККККККККККККККККККК & K20 \\
\hline & КККККККККККККККККККККККК & K24 \\
\hline \multirow{2}{*}{$\mathrm{K}$ and $\mathrm{P}$ type } & КРРКРРКРРКРРКРРКРРКРРКРР & KPP24 \\
\hline & ККРККРККРККРККРККРККРККР & KKP24 \\
\hline RP type & RPRPRPRPRPRPRPRPRPRPRPRP & $\mathrm{RP} 24$ \\
\hline
\end{tabular}

\section{Materials and Methods}

\subsection{Materials}

All 9-fluorenylmethyloxycarbonyl (Fmoc) amino acid derivatives and solid phase peptide synthesis resin were purchased from Watanabe Chemical Industries, Ltd. (Hiroshima, Japan). All other reagents including organic solvents were purchased from FUJIFILM Wako Pure Chemical Corporation (Osaka, Japan). 


\subsection{Peptide Synthesis}

KP24-related peptides that induce the cell aggregate were synthesized by the solid phase peptide synthesis procedure [19-21]. The KP24 and its related peptides were synthesized on Alko-PEG resin using a handmade standard manual Fmoc-protocol with a 4-(4,6-dimethoxy-1,3,5-triazin-2-yl)-4-methylmorpholinium chloride (DMT-MM) activation procedure [22]. $\mathrm{N}-\alpha$-(9-fluorenylmethoxycarbonyl)-L-proline-tritylcarboxamidomethyl polyethylene glycol resin (Fmoc-P-TrtA-PEG-Resin) $(0.20 \mathrm{mmol})$ was placed in a polypropylene column (KSU-6000-30, Funakoshi Co., Ltd., Tokyo, Japan) and washed three times with $\mathrm{N}, \mathrm{N}$-dimethylformamide (DMF) and methanol. The resin was swollen with $25 \%$ $(w / v)$ dimethyl sulfoxide (DMSO)/DMF for $30 \mathrm{~min}$. The mixture was then reacted with $20 \%(w / v)$ piperidine (PPD)/DMF for $30 \mathrm{~min}$ to deprotect the Fmoc group. Then, $0.6 \mathrm{mmol}$ Fmoc-protecting amino acid, $0.06 \mathrm{mmol} \mathrm{N}$-methylmorphiline, and $1.2 \mathrm{mmol}$ DMT-MM were added to the resin. The condensation reaction was run for $120 \mathrm{~min}$. The resin was washed six times with DMF for 1 min each time. The Fmoc group deprotection and condensation reactions were repeated to synthesize the Pro-Lys(Boc) 12 -TrtA-PEG-Resin. Finally, peptide protecting group deprotection and resin cleavage were conducted under acidic conditions. The protected peptide-TrtA-PEG-Resin and the cleavage mixture $(9.50 \mathrm{~mL}$ trifluoroacetic acid (TFA), $0.50 \mathrm{~mL}$ pure water) were stirred for $150 \mathrm{~min}$. The KP24 peptide was dialyzed with a membrane with a molecular weight cutoff range of 100-500 Da (Spectra/Pro Dialysis Membrane Biotech CE Tubing, MWCO: 100-500 D).

Finally, all peptide was purified by high-performance liquid chromatography (HPLC 8020 System; Tosoh Corp., Tokyo, Japan; Column: TSKgel-ODS-100V $5 \mu \mathrm{m}$ ) with a gradient of water/acetonitrile containing $0.1 \%$ TFA. All peptides were identified by matrix-assisted laser desorption/ionization mass spectrometry (MALDI-TOF-MS; Microflex LRF System, Bruker Corp., Billerica, MA, USA) using $\alpha$-cyano-4-hydroxycinnamic acid as a matrix. Peptide solutions were carried out using Congo-red assays according to the manufacturer's protocol (Cosmo Bio Co., Ltd., Tokyo, Japan), so these results were negative [23].

\subsection{Cells and Culture}

Mouse fibroblasts (L929) (RIKEN Biosource Research Center, Ibaraki, Japan) were cultured in Dulbecco's modified Eagle's medium (DMEM: Nissui Pharmaceutical Co., Ltd., Tokyo, Japan) containing 10\% fetal bovine serum (FBS; HyClone, Cytiva, Sheffield, UK), $100 \mathrm{U} / \mathrm{mL}$ penicillin, and $100 \mu \mathrm{g} / \mathrm{mL}$ streptomycin (Invitrogen). All cells were maintained at $37^{\circ} \mathrm{C}$ in a humidified $5 \% \mathrm{CO}_{2} / 95 \%$ air atmosphere. Eagle's Minimal Essential Medium (EMEM: Nissui Pharmaceutical Co., Ltd., Tokyo, Japan) powder, $2.82 \mathrm{~g}$ was dissolved in $261 \mathrm{~mL}$ of ultrapure water, sterilized in an autoclave at $120{ }^{\circ} \mathrm{C}$ for $15 \mathrm{~min}$, and then filtered and sterilized. To prepare 10\% $(w / v)$ FBS EMEM medium, $7.50 \%$ sodium hydrogen carbonate $\left(\mathrm{NaHCO}_{3}\right)$ aqueous solution $6.00 \mathrm{~mL}, 3 \%$ L-glutamine aqueous solution $3.00 \mathrm{~mL}$, and $30 \mathrm{~mL}$ of FBS were added. In addition, $2.82 \mathrm{~g}$ of Eagle's Minimal Essential Medium (EMEM) powder was dissolved in $291 \mathrm{~mL}$ of ultrapure water, sterilized in an autoclave at $120{ }^{\circ} \mathrm{C}$ for $15 \mathrm{~min}$, and then filtered and sterilized. To prepare serum-free EMEM medium, $7.50 \% \mathrm{NaHCO}_{3}$ aqueous solution $6.00 \mathrm{~mL}$ and $3 \% \mathrm{~L}$-glutamine $3.00 \mathrm{~mL}$ of aqueous solution were added.

\subsection{Cell Cytotoxicity Test}

For cytotoxicity testing of KP, KA, KK, and RK type peptides by MTT assay (Dojindo Laboratories, Kumamoto, Japan), peptide/serum-free EMEM medium was prepared and sterilized by filtration. A $2.0 \times 10^{5}$ cells $/ \mathrm{mL}$ cell suspension was prepared using L929. Fifty $\mu \mathrm{L}$ of the cell suspension was seeded on a 96-well plate (IWAKI microplate 96 Well with Lid Flat Bottom, 3860-096, AGC Techno Glass Co., Ltd., Shizuoka, Japan) and $50 \mu \mathrm{L}$ of the peptide solution $(0.01,0.1,1.0,2.0 \mathrm{mg} / \mathrm{mL})$ was added. After an incubation period for $24 \mathrm{~h}$ under the $5 \% \mathrm{CO}_{2}, 37^{\circ} \mathrm{C}$ condition, the supernatant of each well was removed and serumfree EMEM medium was added at $100 \mu \mathrm{L} /$ well. $10 \mu \mathrm{L} /$ well of WST-8 solution was added to each well and incubated for $2 \mathrm{~h}$ under $5 \% \mathrm{CO}_{2}, 37^{\circ} \mathrm{C}$. Then, using a microplate reader 
(infinite F50, TECAN Japan Co., Ltd., Kanagawa, Japan), the absorbance was measured at a measurement wavelength of $450 \mathrm{~nm}$ and a reference wavelength of $600 \mathrm{~nm}$. Furthermore, cell morphology was observed using an optical microscope (OLYMPUS CKX41, Olympus Corp., Tokyo, Japan)

\subsection{Cell Aggregate-Inducing Experiment}

The method for creating a cell aggregate follows. L929 was cultured in 10\% (w/v) FBS EMEM medium under the $37^{\circ} \mathrm{C}$ and $5 \% \mathrm{CO}_{2}$ condition. The cells were detached from the plate by trypsin treatment. A $10 \%(w / v)$ FBS EMEM medium was added to the cells to suppress trypsin activity. After removing the trypsin/EDTA solution, it was resuspended in the serum-free EMEM medium. The L929 cells were seeded so as to have a cell density of $5.0 \times 10^{4}$ cells/well (IWAKI microplate 96 Well with Lid Flat Bottom, 3860-096, AGC Techno Glass Co., Ltd., Shizuoka, Japan). After preculturing for 6 h, each peptide solution dissolved in the serum-free EMEM medium was added to a concentration of $1.0 \mathrm{mg} / \mathrm{mL}$ and cultured. The peptide solution was filtered with a syringe filter $(0.1 \mu \mathrm{m})$. It seems that peptide aggregate was not a problem in this experiment. The day when the peptide-containing medium was added onto the cells was defined as the day 0 , and changes over time were observed every day for 7 days. Live/dead assays were conducted using a Live/Dead Viability/Cytotoxicity Assay (Invitrogen) according to the manufacturer's protocol. The cell aggregates were rinsed once with PBS, 7 days after incubation, and then incubated with the mixed solution of $2 \mathrm{mM}$ Calcein AM (Dojindo, Kumamoto, Japan) and $4 \mathrm{mM}$ ethidium homodimer-1 solution in PBS for $15 \mathrm{~min}$ at room temperature in the dark, followed by observation using a microscope (ZEISS LSM 800 with Airyscan, Carl Zeiss Co., Ltd., Obrtkochen, Germany).

\subsection{Measuring the Size of Cell Aggregates and Sphericity}

Three-dimensional analysis of cell aggregates was performed using Mil-Cell (Sumitomo Electric Industries, Ltd. Osaka, Japan) and 3D imaging analysis software.

The size of the cell aggregate was measured under microscope observation, and analysis was performed using OLYMPUS imaging software cellSens (Olympus Corp. Tokyo, Japan).

\section{Results and Discussion}

\subsection{Peptide Synthesis}

Five types of 13 sequences of peptides in Table 1 were synthesized manually by solid phase peptide synthesis. All peptides were characterized by HPLC, MALDI-TOFMS, and amino-acid analysis. All peptides were purified by RT-HPLC to a single peak. Results of MALDI-TOF-MS spectra $\mathrm{m} / \mathrm{Z}$ of $[\mathrm{M}+1]^{+},[\mathrm{M}+\mathrm{Na}]^{+}$, and $[\mathrm{M}+\mathrm{K}]^{+}$are shown in Table 2 . These results suggest that 13 kinds of peptides were synthesized, as intended in the molecular design.

Table 2. Results of peptide synthesis and bioactivity of designed peptide.

\begin{tabular}{|c|c|c|c|c|c|c|}
\hline \multirow{2}{*}{ Code } & \multicolumn{4}{|c|}{ MALDI-TOF-MS Data } & \multirow{2}{*}{$\begin{array}{l}\text { Cell Toxicity } \\
\text { (IC50: } \mathrm{mg} / \mathrm{mL} \text { ) }\end{array}$} & \multirow{2}{*}{ Cell Aggregate-Inducing Activity } \\
\hline & Fw (Cal.) & {$[\mathrm{M}]^{+},[\mathrm{M}+1]^{+}$} & {$[\mathrm{M}+\mathrm{Na}]^{+}$} & {$[\mathbf{M}+\mathbf{K}]^{+}$} & & \\
\hline KP20 & 2271.01 & 2272.7 & - & 2311.4 & - & 0 \\
\hline KP24 & 2721.61 & 2721.9 & 2743.4 & 2760.6 & - & 0 \\
\hline KP28 & 3172.21 & 3170.1 & 3192.1 & - & $0.1<1.0 * 1$ & - \\
\hline KP32 & 3622.81 & 3619.3 & 3643.2 & 3657.5 & $0.01<0.1 * 2$ & - \\
\hline KA16 & 1612.09 & 1613.2 & - & - & - & - \\
\hline KA20 & 2010.61 & 2011.7 & 2033.6 & - & - & - \\
\hline KA24 & 2409.13 & 2410.9 & - & - & - & - \\
\hline K16 & 2068.79 & - & 2091.4 & - & $0.1<1.0 * 3$ & - \\
\hline K20 & 2581.45 & 2580.8 & 2603.3 & - & $0.1<1.0 * 4$ & - \\
\hline K24 & 3094.15 & 3093.7 & 3115.7 & - & $0.1<1.0 * 5$ & - \\
\hline KPP24 & 2597.37 & 2598.8 & 2620.1 & 2637.2 & - & 0 \\
\hline KKP24 & 2845.85 & 2847.3 & - & - & - & 0 \\
\hline $\mathrm{RP} 24$ & 3057.63 & 3057.3 & - & - & $0.01<0.1 * 6$ & - \\
\hline
\end{tabular}




\subsection{Cell Cytotoxicity Test}

The cytotoxicity results are shown in Table 2. The KP type was found toxic when the chain length was 28 residues or more. The IC50 value of KP32 and RP24 was $0.01<0.1 \mathrm{~g} / \mathrm{mL}$ and that of KP28 was $0.1<1.0 \mathrm{~g} / \mathrm{mL}$. All KK type peptides had weaker cytotoxic activity compared to KP32. The KK type of peptide had much positive charge compared with lysine containing KPP and KKP peptides. The cytotoxic activity of these peptides can be inferred to be the effect of positively charged lysine residues [24-26]. Furthermore, RP24 showed the strongest cytotoxic activity. This was considered due to the fact that the arginine residue has a stronger positive charge than the lysine residue. The peptides showing cytotoxic activity are thought to have cells damaged by changing the cell surface potential from interacting with the cell membrane. The KA type peptides and KP type, KP20, which has a shorter chain length, was not found cytotoxic. From these results, it can be inferred that the number of positively charged Lys and Arg residues affects cytotoxicity. It was difficult to decide to exact IC50 value because the cell cytotoxicity test was measured at only four points. Thus, cell aggregate inducing experiment was carried out at a noncytotoxicity level of $1.0 \mathrm{~g} / \mathrm{mL}$ peptide concentration $(1.0 \mathrm{~g} / \mathrm{mL}=\mathrm{KP} 24,367 \mu \mathrm{M}$; KPP24, $385 \mu \mathrm{M}$; KKP24, $351 \mu \mathrm{M})$.

\subsection{Cell Aggregate-Inducing Experiment}

As shown in Table 2, the cell aggregate-inducing activity was observed for four kinds of peptides: KP20, KP24, KPP24, and KKP24. Furthermore, these methods used a chemical cell aggregation method and were completely new methods that have never existed before. It was found that a certain peptide concentration and cell density were optimum for cell aggregate induction by KP24, which were $1.0 \mathrm{mg} / \mathrm{mL}$ and $5.0 \times 10^{4}$ cells $/ \mathrm{mL}$. When the cell density was low, the cell aggregate could not be induced. The reason was that cell migration was essential for the formation of cell aggregates, so the distance between cells was important for aggregation. The optimized condition of adding peptide solution was $6 \mathrm{~h}$ after cell seeding and preattachment. The results of inducing cell aggregates under optimum conditions using KP24 are shown in Figure 1. Cell migration was observed from the first day after adding the peptide, and cell aggregation was observed on a plane surface two days later. Three days after the addition of the peptide, cell migration from the plane to three dimensions was observed, and on the fourth day, small spherical cell aggregates came to recognition. On the fifth day, it had transitioned to a spherical cell aggregate. Six days after the addition of the peptide, a cell aggregate was formed, and in addition, the outer shell (proliferating zone) was covered with a stable inner cell. Once the proliferating zone was formed around the cell aggregate, on day 6 after the addition of KP24, the cell aggregate was held stable. A live/dead assay image suggested all of the cell-composed cell aggregates were live at 6 days (Figure 1C). Thus, the microphotograph of Mil-Cell analysis indicated that the cell aggregates certainly had a three-dimensional structure (Figure 1D). The average of sphericity of the cell aggregate induced by KP24 was about $68 \%$, as calculated by the Mil-Cell 3D imaging analysis software. Figure 2 shows the results of the cell aggregate induced using the KP20, KKP24, and KPP24 peptides under the same conditions in which the cell aggregate was induced in KP24. In all of KP20, KP24, KKP24, and KPP24, the peptides induced the cell aggregates, and for KP20, KP24, and KPP24, spherical cell aggregates were obtained. On the other hand, KKP24 showed a behavior in which small cell aggregates of about 10 cells were formed in the initial stage, and then the aggregates further aggregated with each other. The size distribution of the cell aggregate is shown in Figure 3. Assuming that the appropriate size of the cell aggregate was around $100 \mu \mathrm{m}, \mathrm{KP} 24$ was considered suitable for inducing the cell aggregate. As for KP20, many over $100 \mu \mathrm{m}$ were observed. KKP24 was the result of the extremes of small cell aggregates and large cell aggregates. 
A
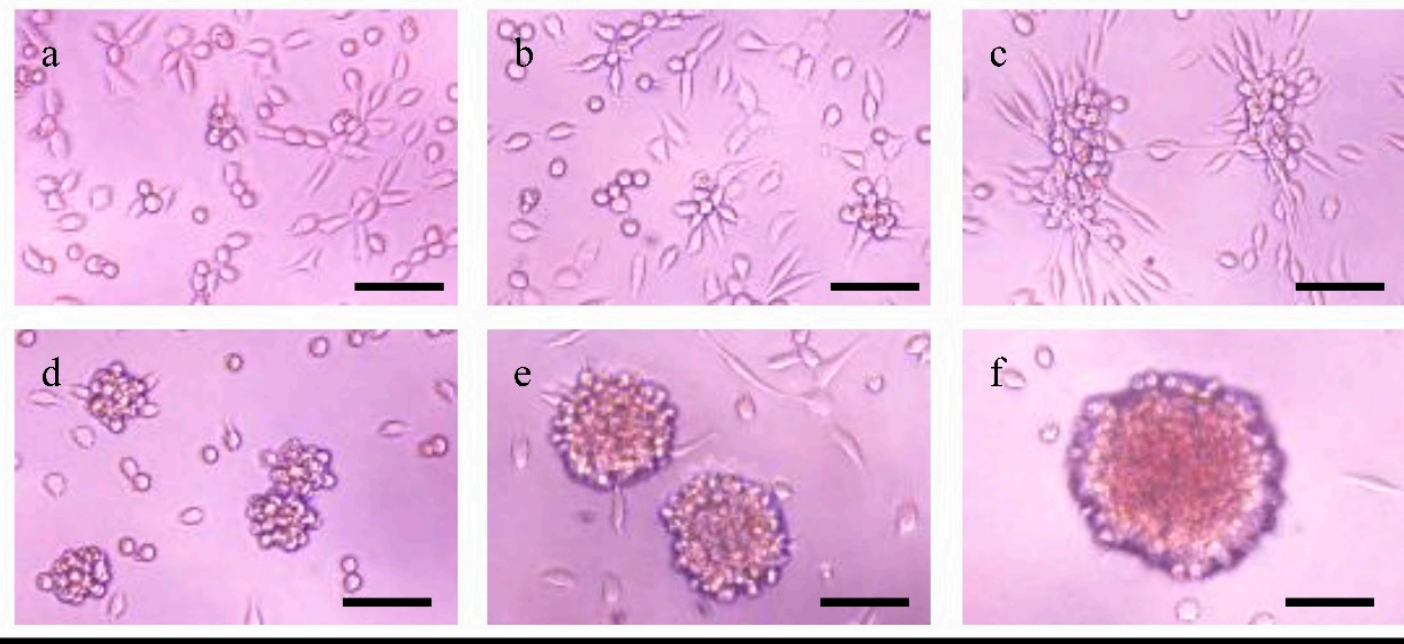

B
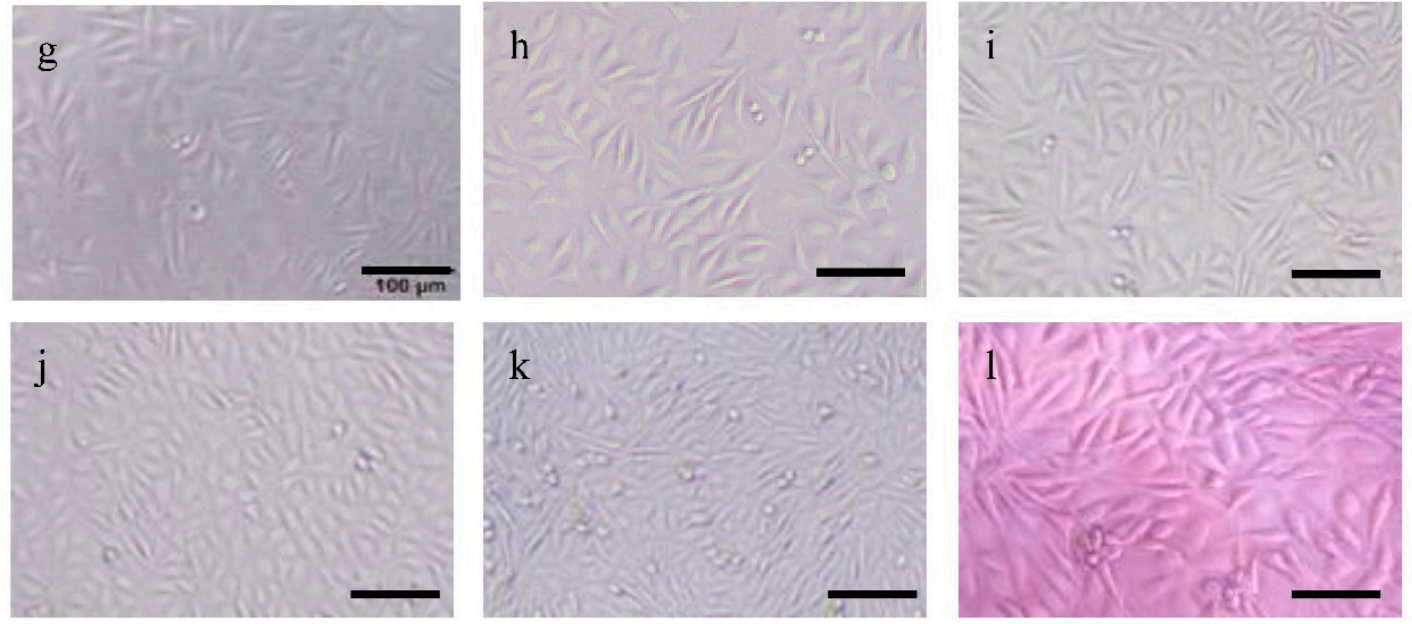

C
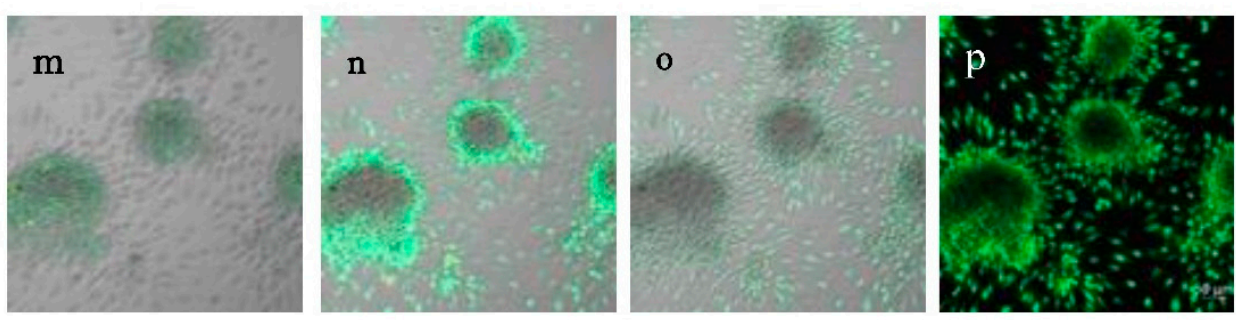

D
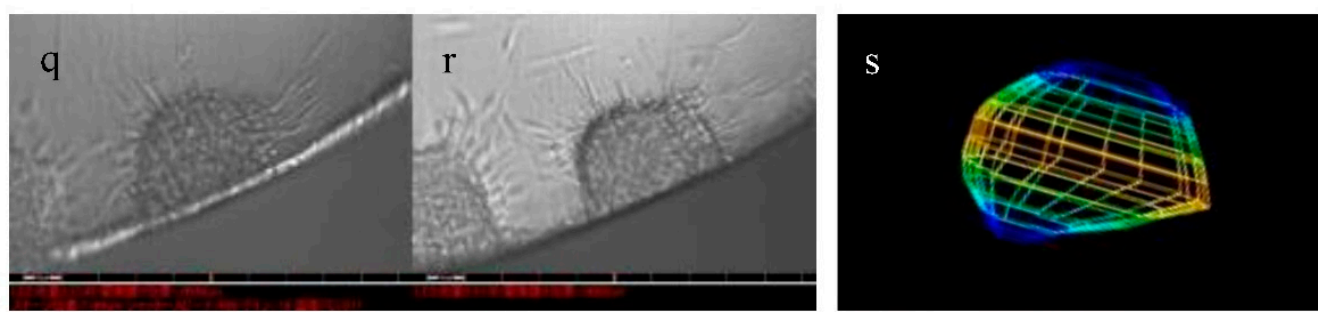

Figure 1. Results of cell aggregate induced by adding of KP24 peptide ( $\times 10$ and scale bar: $100 \mu \mathrm{m})$. (A) Addition of peptide. (B) Control-incubation time, 1-6 days; a and g, 1 day; b and h, 2 days; $c$ and i, 3 days; $d$ and j, 4 days; e and k, 5 days; $f$ and 1, 6 days; cell density, $5.0 \times 10^{4}$ cells $/ \mathrm{mL}$; peptide concentration, $1.0 \mathrm{mg} / \mathrm{mL}$. (C) Live/dead assay photographs of confocal laser scanning microscope (KP24, 6 days)—-m, top; $n$, center layer; o, bottom observation; $\mathrm{p}$, live/dead assay image. (D) Microphotograph of Mil-Cell analysis and 3D analysis-q, bottom view; r, side view; s, 3D image analysis. 

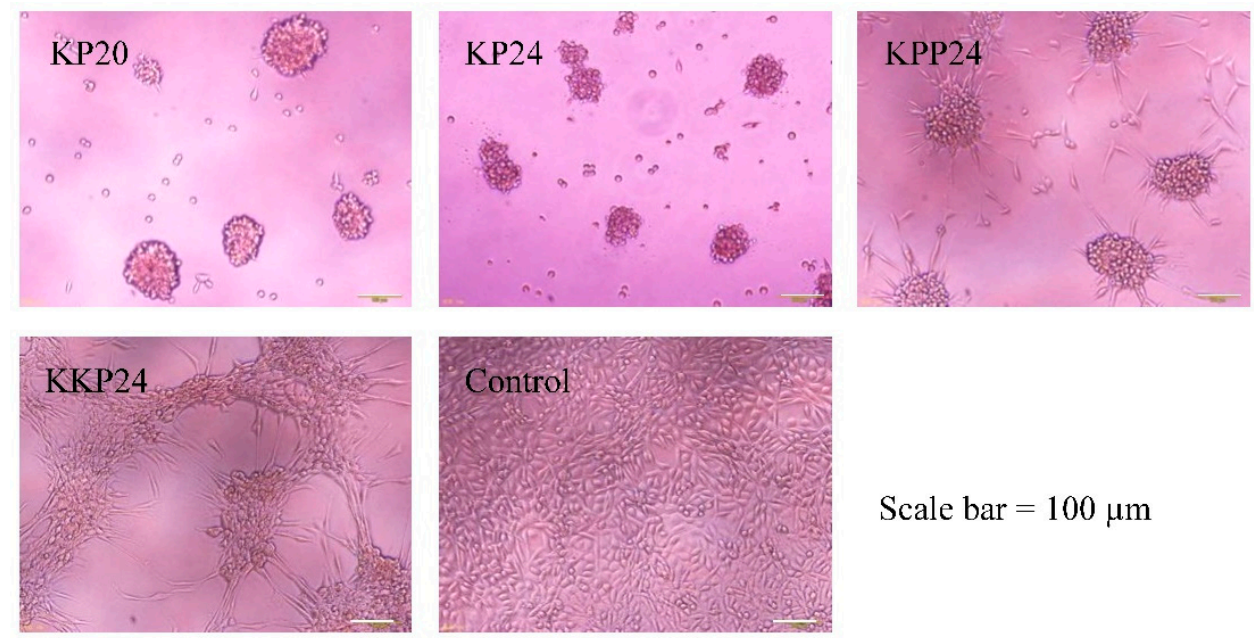

Scale bar $=100 \mu \mathrm{m}$

Figure 2. Effect of peptide sequence on inducing cell aggregation (day 6). Cell density, $5.0 \times 10^{4}$ cells $/ \mathrm{mL}$; peptide concentration, $1.0 \mathrm{mg} / \mathrm{mL}$; scale bar: $100 \mu \mathrm{m}$.

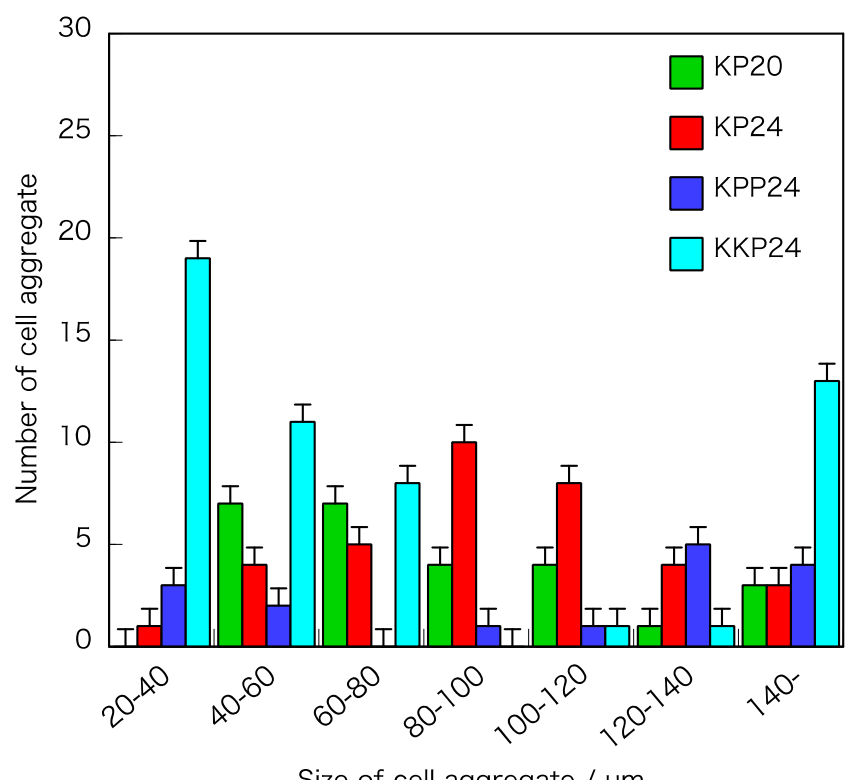

Figure 3. Distribution of cell aggregate size.

From these results, it was inferred that a chain length of about 20 residues was required for cell aggregate induction, and that a positive charge of lysine and proline was required. Since proline was contained in the peptide chain, this peptide structure was considered a rod-like conformation.

As a mechanism, it can be inferred that this peptide interacts with the cell membrane; some signal was transmitted inside the cell to stimulate actin fibers; thus, cell migration occurred and cell aggregates were formed $[27,28]$. The detailed mechanism is unknown at this time. However, since these peptides can induce cell aggregates by only adding them to the cell culture medium, our method is simpler and can be mass produced, as compared to the hanging drop method and the U-shaped cell culture plate method. It is considered a new concept for spheroid preparation [29,30]. For future work, we will try to induce cell aggregation by using human fibroblast, hepatocyte, and mesenchymal stem cells (hMSC).

\section{Conclusions}

We succeeded in inducing cell aggregates using the chemical technique of adding peptides to the medium. There were four types of peptide sequences, namely KP20, KP24, 
KKP24, and KPP24, and cell aggregate induction depended on the peptide sequence. It is presumed that a chain length of about 20 residues is required for cell aggregate induction, and a structure formed by the positive charge of lysine and proline is required. We believe our methods are a completely new method for basic research and the biomedical engineering field.

Author Contributions: Design and study planning, Y.F., M.T., and Y.H.; conceptualization, Y.H.; methodology, Y.H., Y.F., and M.T.; validation, Y.F., I.A., M.T., and T.I.; analysis and investigation, Y.F., I.A., M.T., and T.I.; writing—original draft preparation, Y.H.; funding acquisition, Y.H. All authors have read and agreed to the published version of the manuscript.

Funding: This work was financially supported by MEXT-Private University Research Branding Project (2016-2019) and the Japan Society for the Promotion of Science (JSPS) Grant-in-Aid for Scientific Research (C) (grant number16K01400).

Institutional Review Board Statement: Not applicable.

Informed Consent Statement: Not applicable.

Data Availability Statement: Not applicable.

Conflicts of Interest: The authors declare no conflict of interest. The authors declare that they have no known competing financial interests or personal relationships that could have appeared to influence the work reported in this paper.

\section{References}

1. Griffith, L.G.; Swartz, M.A. Capturing complex 3D tissue physiology in vitro. Nat. Rev. Mol. Cell Biol. 2006, 7, 211-224. [CrossRef]

2. Pampaloni, F.; Reynaud, E.G.; Stelzer, E.H. The third dimension bridges the gap between cell culture and live tissue. Nat. Rev. Mol. Cell Biol. 2007, 8, 839-845. [CrossRef]

3. Abbott, A. Cell culture: Biology's new dimension. Nature 2003, 424, 870-872. [CrossRef]

4. Kim, S.; Kim, E.-M.; Yamamoto, M.; Park, H.; Shin, H. Engineering Multi-Cellular Spheroids for Tissue Engineering and Regenerative Medicine. Adv. Healthc. Mater. 2020. [CrossRef]

5. Lin, R.-Z.; Chang, H.-Y. Recent advances in three-dimensional multicellular spheroid culture for biomedical research. Biotechnol. J. 2008, 3, 1172-1184. [CrossRef]

6. Kozyra, M.; Johansson, I.; Nordling, A.; Ullah, S.; Lauschke, V.M.; Ingelman-Sundberg, M. Human hepatic 3D spheroids as a model for steatosis and insulin resistance. Sci. Rep. 2018, 8, 14297. [CrossRef]

7. Bauer, S.; Huldt, C.W.; Kanebratt, K.P.; Durieux, I.; Gunne, D.; Andersson, S.; Ewart, L.; Haynes, W.G.; Maschmeyer, I.; Winter, A.; et al. Functional coupling of human pancreatic islets and liver spheroids on-a-chip: Towards a novel human ex vivo type 2 diabetes model. Sci. Rep. 2017, 7, 14620. [CrossRef]

8. Xu, Y.; Shi, T.; Xu, A.; Zhang, L. 3D spheroid culture enhances survival and therapeutic capacities of MSCs injected into ischemic kidney. J. Cell. Mol. Med. 2016, 20, 1203-1213. [CrossRef]

9. Alhaque, S.; Themis, M.; Rashidi, H. Three-dimensional cell culture: From evolution to revolution. Philos. Trans. R. Soc. B Biol. Sci. 2018, 373, 20170216. [CrossRef]

10. Fennema, E.; Rivron, N.; Rouwkema, J.; van Blitterswijk, C.; de Boer, J. Spheroid culture as a tool for creating 3D complex tissues. Trends Biotechnol. 2013, 31, 108-115. [CrossRef]

11. Cesarz, Z.; Tamama, K. Spheroid Culture of Mesenchymal Stem Cells. Stem Cells Int. 2016, 2016, 9176357. [CrossRef]

12. Park, I.-S.; Chung, P.-S.; Ahn, J.C. Enhancement of Ischemic Wound Healing by Spheroid Grafting of Human Adipose-Derived Stem Cells Treated with Low-Level Light Irradiation. PLoS ONE 2015, 10, e0122776.

13. Guo, L.; Ge, J.; Zhou, Y.; Wang, S.; Zhao, R.C.H.; Wu, Y. Three-dimensional spheroid-cultured mesenchymal stem cells devoid of embolism attenuate brain stroke injury after intra-arterial injection. Stem Cells Dev. 2014, 23, 978-989. [CrossRef]

14. Hsu, S.H.; Hsieh, P.S. Self-assembled adult adipose-derived stem cell spheroids combined with biomaterials promote wound healing in a rat skin repair model. Wound Repair Regen. 2015, 23, 57-64. [CrossRef]

15. Laschke, M.W.; Menger, M.D. Life is 3D: Boosting Spheroid Function for Tissue Engineering. Trends Biotechnol. 2017, 35, 133-144. [CrossRef] [PubMed]

16. Giovannini, S.; Diaz-Romero, J.; Aigner, T.; Heini, P.; Mainil-Varlet, P.; Nesic, D. Micromass co-culture of human articular chondrocytes and human bone marrow mesenchymal stem cells to investigate stable neocartilage tissue formation in vitro. Eur. Cell Mater. 2010, 20, 245-259. [CrossRef]

17. Li, Y.; Guo, G.; Li, L.; Chen, F.; Bao, J.; Shi, Y.; Bu, H. Three-dimensional spheroid culture of human umbilical cord mesenchymal stem cells promotes cell yield and stemness maintenance. Cell Tissue Res. 2015, 360, 297-307. [CrossRef]

18. Kibschull, M. Differentiating Mouse Embryonic Stem Cells into Embryoid Bodies in AggreWell Plates. Cold Spring Harb. Protoc. 2017. [CrossRef] 
19. Fields, G.B.; Noble, R.L. Solid phase peptide synthesis utilizing 9-fluorenylmethoxycarbonyl amino acids. Int. J. Pept. Protein Res. 1990, 35, 162-214. [CrossRef]

20. Alberico, F.; Kneib-Cordonier, N.; Biancalana, S.; Gera, L.; Masada, R.I.; Hudson, D.; Barany, G. Preparation and application of the 5-(4-(9-fluorenylmethyloxycarbonyl)aminomethyl-3,5-dimethoxyphenoxy)-valeric acid (PAL) handle for the solid-phase synthesis of C-terminal peptide amides under mild conditions. J. Org. Chem. 1990, 55, 3730-3743. [CrossRef]

21. Yajima, H.; Fujii, N.; Funakoshi, S.; Watanabe, T.; Murayama, E.; Otaka, A. New strategy for the chemical synthesis of proteins. Tetrahedron 1988, 44, 805-819. [CrossRef]

22. Hioki, K.; Kobayashi, K.; Ohkihara, R.; Tani, S.; Kunishima, M. Preparation of weienreb amide using 4-(4,6-dimethoxy-1,3,5triazin-2-yl)-4-methylmorpholinium chloride (DMT-MM). Chem. Pham. Bull. 2004, 52, 470-472. [CrossRef]

23. Cooper, T.M.; Stone, M.O. Investigation of Self-Assembly upon Formation of an Electrostatic Complex of Congo Red and a Helical Peptide. Langmuir 1998, 14, 6662-6668. [CrossRef]

24. Nan, Y.H.; Lee, S.H.; Kim, H.J.; Shin, S.Y. Mammalian cell toxicity and candidacidal mechanism of Arg- or Lys-containing Trp-rich model antimicrobial peptides and their d-enantiomeric peptides. Peptides 2010, 31, 1826-1831. [CrossRef] [PubMed]

25. Tamamura, H.; Arakaki, R.; Funakoshi, H.; Imai, M.; Otaka, A.; Ibuka, T.; Nakashima, H.; Murakami, T.; Waki, M.; Matsumoto, A.; et al. Effective lowly cytotoxic analogs of an HIV-cell fusion inhibitor, T22 ([Tyr5,12, Lys7]-polyphemusin II). Med. Chem. 1998, 6, 231-238. [CrossRef]

26. Yang, S.T.; Shin, S.Y.; Lee, C.W.; Kim, Y.C.; Hahm, K.S.; Kim, J.I. Selective cytotoxicity following Arg-to-Lys substitution in tritrpticin adopting a unique amphipathic turn structure. FEBS Lett. 2003, 540, 229-233. [CrossRef]

27. Turner, P.A.; Weeks, C.A.; McMurphy, A.J.; Janorkar, A.V. Spheroid organization kinetics of H35 rat hepatoma model cell system on elastin-like polypeptide-polyethyleneimine copolymer substrates. J. Biomed. Mater. Res. A 2014, 102, 852-861. [CrossRef]

28. Weeks, C.A.; Aden, B.; Zhang, J.; Singh, A.; Hickey, R.D.; Kilbey, S.M.; Nyberg, S.L.; Janorkar, A.V. Effect of amine content and chemistry on long-term, three-dimensional hepatocyte spheroid culture atop aminated elastin-like polypeptide coatings. $J$. Biomed. Mater. Res. A 2017, 105, 377-388. [CrossRef]

29. Weeks, C.A.; Newman, K.; Turner, P.A.; Rodysill, B.; Hickey, R.D.; Nyberg, S.L.; Janorkar, A.V. Suspension culture of hepatocytederived reporter cells in presence of albumin to form stable three-dimensional spheroids. Biotechnol. Bioeng. 2013, 110, $2548-2555$. [CrossRef]

30. Song, L.; Yuan, X.; Jones, Z.; Griffin, K.; Zhou, Y.; Ma, T.; Li, Y. Assembly of Human Stem Cell-Derived Cortical Spheroids and Vascular Spheroids to Model 3-D Brain-like Tissues. Sci. Rep. 2019, 9, 5977. [CrossRef] [PubMed] 